\title{
REVIEW
}

\section{Sueños al pairo: una mirada sobre el drama del Mariel cuarenta años después}

\author{
Jorge Luis Lanza Caride \\ ACPC (Asociación Cubana De La Prensa Cinematográfica), CU \\ lanzajorge745@gmail.com
}

La crisis del Mariel ha sido abordada en diferentes filmes rodados tanto en Cuba como en la diáspora en EE.UU, incluso existen enfoques hollywoodenses sobre este trascendental acontecimiento histórico que estremeció la sociedad estadounidense en su momento. A diferencia de esos filmes el documental Sueños al pairo posee un enfoque novedoso y enriquecedor no sólo porque es el desgarrador testimonio del trovador exiliado en Mike Porcel, sino porque reafirma el drama que experimentaron muchos artistas cubanos que ante tanta represión vieron en el puente del Mariel una puerta a la libertad.

Palabras clave: Éxodo del Mariel; crisis migratoria; diáspora cubana en EE.UU; represión

El proyecto de rodar el documental Sueños al pairo sobre el trovador cubano exiliado en EE.UU. Mike Porcel se remonta al período en el cual sus realizadores, Jorge Luis Aparicio y Fernando Fraguela, cursaban estudios en la FAMCA (Facultad de las Artes de los Medios de Comunicación Audiovisual), perteneciente al Instituto Superior de Arte. Presentaron el proyecto en la sección Haciendo Cine de la XVI edición de la Muestra Joven de Cine Cubano y posteriormente el ICAIC (Instituto Cubano del Arte y la Industria Cinematográfica) no sólo apoyó la producción del documental, sino que permitió el acceso a materiales de archivo fílmico sobre los sucesos del Mariel. ${ }^{1}$ Aunque Sueños al pairo no aborda directamente la problemática del Mariel, la crisis del Mariel representó un antes y un después en la vida del cantautor. De ahí el interés de los realizadores en incorporar fragmentos de dichos materiales a su documental.

Antes de 1980, Mike Porcel era considerado uno de los principales exponentes de La Nueva Trova, movimiento musical que alcanzó su máxima popularidad en Cuba entre la década del sesenta y setenta, identificado con la ideología revolucionaria y el auge de la izquierda progresista en Latinoamérica de la época, de carácter radical. ${ }^{2}$ La obra de Mike se caracterizaba por combinar de manera armónica y con un sello estético muy personal la poesía con complejas melodías de guitarra que develaban notables influencias de estilos musicales como la música clásica, el rock, jazz, ritmos étnicos, y el new age.

Entre sus composiciones musicales más trascendentales se encuentra En busca de una nueva flor, ganadora del Festival Mundial de la Juventud y los Estudiantes que se llevó a cabo en La Habana en 1978. Ese mismo año contribuyó a la fundación de la agrupación musical de rock Síntesis, la cual fusionó ese género con los ritmos afrocubanos.

Sin embargo, Mike, al igual que muchos artistas de su generación, desencantados con la censura, la intolerancia cultural, y el dogmatismo imperante en la Cuba de los setenta, intentó marcharse por el puente del Mariel en 1980, pero el gobierno cubano le negó la salida. Aun así, sufrió las humillaciones y actos de repudio que acompañaron el éxodo migratorio más grande en la historia de la nación cubana, cuando 125.000 cubanos abandonaron el país mediante embarcaciones costeadas por los familiares en EE.UU, quienes se arruinaron con el objetivo de sacar a sus familiares en la isla. Miles de individuos también salieron en esas mismas embarcaciones bajo la presión social del gobierno.

\footnotetext{
Para mas información sobre la Muestra Joven de Cine Cubano, consulta muestrajoven.cult.cu/.

${ }^{2}$ Para mas información sobre Mike Porcel, consulta mikeporcel.com/bio-espanol.
} 
A partir de la negativa de otorgarle la salida, la existencia de Mike Porcel se tornó en una verdadera odisea, al permanecer alrededor de nueve años marginado de la vida cultural de la isla, condenado al ostracismo por las mismas autoridades que organizaron esos vergonzosos actos de repudio, de los que también fue víctima. Durante varios años sobrevivió tocando el órgano en algunas iglesias de la ciudad de La Habana y en 1988 tuvo la osadía de comparecer ante una Comisión de Derechos Humanos de la ONU que inspeccionó Cuba e inmediatamente el gobierno le otorgó la salida, radicándose en España hasta reencontrarse con su familia en EE.UU. en 1994, donde reside en la actualidad.

Resulta comprensible que un documental rodado en Cuba sobre un tema tan sensible provocara profundas controversias. Pero no por ello dejó de causar gran impacto cuando el ICAIC-institución supuestamente partidaria en años recientes de una política cultural más aperturista y libertaria para el beneficio de los cineastas independientes-censuró Sueños al pairo cuando fue destinado a concursar en la XIX edición del espacio de la Muestra Joven en 2020.

El conflicto fue provocado por la negativa del ICAIC a la utilización de las imágenes de archivo relacionados con la crisis del Mariel que los realizadores habían tomado del Noticiero ICAIC Latinoamericano, fundado en 1959 por el cineasta Santiago Álvarez, con la finalidad de informar sobre la realidad cubana y latinoamericana desde una perspectiva anti-imperialista. ${ }^{3}$

Hoy en día diversos académicos y estudiosos del cine cubano consideran el Noticiero ICAIC Latinoamericano una herramienta ideológica y comunicacional estratégica de la Cuba socialista y reconocen sus aportes estéticos al documental cubano hasta su desaparición en 1990, tras la llegada de la crisis económica de los noventa. De esta manera, el pretexto esgrimido por el ICAIC para desautorizar el acceso a las referidas fuentes no radicó tanto en que eran materiales clasificados o totalmente desconocidos, sino en su desacuerdo con el tratamiento expuesto por el documental sobre los acontecimientos de 1980.

Efectivamente, el tratamiento desacralizador de las imágenes de archivo que expone Sueños al pairo constituye una de las claves que explican su impacto cultural tanto en Cuba como fuera de ella. Los realizadores se apropiaron de un material histórico para presentar una contra-historia, es decir, una desacralización de la historia oficial. Para el crítico de cine Reinaldo Lastre:

Desde la perspectiva del documental, las imágenes de 'un pueblo enardecido' no presentan un relato-triunfo, sino del fracaso del proyecto revolucionario. No en vano los realizadores inician su documental con un archivo de un minuto y medio donde evocan el éxodo del Mariel, y los bochornosos actos de repudio organizados por el gobierno alrededor de todo el que decidiera marcharse del país en ese momento.

Comparto las ideas expuestas por el autor, pues si en aquel contexto las imágenes tomadas por Santiago Álvarez para su Noticiero intentaban legitimar la posición oficial sobre la crisis del Mariel, el uso de las imágenes de archivo en Sueños al pairo revela aristas silenciadas y manipuladas por la propaganda oficial en relación a los hechos, como sucedió con algunos incidentes que constituyen el detonante real de la crisis del Mariel. ${ }^{4}$ Me refiero a los sucesos de la Embajada del Perú, cuyas imágenes son expuestas en el documental, así otro suceso patético y triste acontecido en las afueras de la Sección de Intereses de EE.UU en La Habana, cuando cientos de individuos que asistieron a la sede con el objetivo de recibir asilo político fueron reprimidos violentamente por grupos alentados por el gobierno.

Es cierto que la crisis del Mariel había sido tratada anteriormente por el cine cubano a través de obras como el corto Laura de la desaparecida cineasta Ana Rodríguez perteneciente al largometraje de ficción Mujer transparente (1990); La anunciación (2008), de Enrique Pineda Barnet; y Memorias del desarrollo (2010), de Miguel Coyula, basada en la obra homónima de Edmundo Desnoes. Algunas de las imágenes de archivo que aparecen en los inicios de Sueños al pairo también aparecen en otros documentales, como Más allá del Mar (2004), del realizador cubano-estadounidense Lisandro Pérez-Rey, considerado entre los mejores documentales rodados en EE.UU. concebidos desde la perspectiva de un creador de la diáspora cubana en ese país.

Pero a diferencia de los referidos filmes, que han abordado el tema del Mariel desde la ficción o el historicismo, Sueños al pairo obliga al espectador a enfrentar las memorias íntimas y duras de un solo personaje en la isla, los detalles sobre la represión social de la que fue objeto como artista, así como los avatares de su existencia en la diáspora en EE.UU. Lo impresionante es que los recuerdos de Mike Porcel parecen estar

\footnotetext{
${ }^{3}$ Para mas información sobre Santiago Álvarez, consulta santiagoalvarez.com/biografia/.

${ }^{4}$ Aparicio y Fraguela, Sueños al pairo, 2020.
} 
despojados de cualquier vestigio de resentimiento, por lo que el documental no deja de apelar a un discurso reconciliador.

Tras la censura de Sueños al pairo y su imposibilidad de concursar en la Muestra Joven de Cine de 2020, la gran mayoría de los realizadores decidieron retirar sus obras del festival en solidaridad con sus creadores (DDC). El ICAIC reaccionó adoptando la torpe decisión de posponer la edición de la Muestra Joven y, lo más lamentable, destituyó a su presidenta María Carla Valdés, quien se había solidarizado con los jóvenes cineastas, hecho que provocó reacciones de rechazo por parte de prestigiosas figuras del ámbito cultural de la isla como el dramaturgo Norge Espinosa y el crítico de cine Juan Antonio García Borrero.

La censura de Sueños al pairo nos confirma sus efectos contraproducentes en el panorama cultural de la isla, porque en lugar de minimizarse su impacto cultural ha tomado más notoriedad en el espectro mediático, no sólo a nivel nacional, sino también internacional. Gracias a Sueños al pairo, ha aflorado la verdad histórica, a la cual se enfrentan las nuevas generaciones de cubanos ávidos de redescubrirla.

\section{Conflictos de interés}

El autor declara no tener conflictos de interés.

\section{Referencias}

Aparicio, José Luis and Fernando Fraguela, dir. Sueños al pairo, 2020.

DDC. "Editorial: La censura en Cuba hoy y hace 40 años." Diario de cuba. 27 de febrero 2020, diariodecuba. com/cuba/1582818930_12371.html.

Lastre, Reinaldo. "Poder y Estado en el cine cubano del siglo XXI." la Fuga. Fecha de consulta: 21 de noviembre 2020, lafuga.cl/archivo-poder-y-estado-en-el-cine-cubano-del-siglo-xxi/1010.

How to cite this article: Lanza Caride, JL 2021 Sueños al pairo: una mirada sobre el drama del Mariel cuarenta años después. Anthurium, 17(2): 19, 1-3. DOl: https://doi.org/10.33596/anth.459

Published: 14 December 2021

Copyright: (c) 2021 The Author(s). This is an open-access article distributed under the terms of the Creative Commons Attribution 4.0 International License (CC-BY 4.0), which permits unrestricted use, distribution, and reproduction in any medium, provided the original author and source are credited. See http://creativecommons.org/licenses/by/4.0/. 